\title{
An Investment Grade Audit on Proposed Rice husk Power Generation in rural part of Belagavi, India
}

\author{
S. B. Halbhavi ${ }^{1}$, S. G. Kulkarni ${ }^{2}$, Prof. Vani P. Datar ${ }^{3}$ \\ Department of Electrical \& Electronics Engineering, Gogte Institute of Technology, Belgaum, Karnataka, India ${ }^{1,2,3}$
}

\begin{abstract}
Energy demand is increasing exponentially in the developing countries like India due to rapid growth in population and industrial development. Conventional energy sources are depleting at a higher rate hence there is a search to look for different alternatives for electrical energy production. India is one of the world's largest producers of rice, accounting for $20 \%$ of all world rice production. Approximately 120 million tons of rice is produced every crop year. More than $60 \%$ this is processed in local rice mill and producing rice husk as waste biomass. Husk was primarily used for steam production for parboiling and drying process of rice. Rice husk based biomass plant can be an alternate source to meet electricity demand. Since availability of rice husk cannot be predicted instead of using only rice husk as fuel a mixture of biomass can also be used. In this paper proposal for rice husk based power generation and energy audit to recover the investment is discussed.
\end{abstract}

Keywords: Rice husk, green electricity, steam engine, energy audit.

\section{INTRODUCTION}

India is the fourth largest energy producing country in the world and sixth largest energy consumer in the world after the United States, China, and Russia [1]. In recent years, India's energy consumption has been increasing at a relatively fast rate due to population growth and economic development. Rapid urbanization and improving standards of living for millions of Indian households, the demand is likely to grow significantly. Current centralized energy planning of India is dependent on coal and fossil fuel sources. The main concern arises on how to protect the fossil fuel for our coming generation with simultaneously utilizing the different resources of energy for high and sustained economic growth. Pressure to increase its energy supplies and the consequent negative environmental impact of fossil fuels has led India to a conscious policy toward renewable sources [2].

Biomass is one the most important energy sources amongst renewable energies. It is third among the primary energy sources after coal and oil. In India, rice is a major cereal which is nearly 40 percent of total food grain cultivated, and cropped in over 30 percent of its area. The potential of biomass is well known to meet the global energy demand. Foreign exchange on import of fossil fuel and conservation of limited supply of fossil fuel widely depend upon utilization of all other indigenous fuel energy sources. India processes about 120 million tones of paddy per year and provides staple food grain and other valuable products required by the population. In Karnataka the area under paddy was $22,67,400$ hectares with the production of 64, 55,150 tones during 2009-2010. Davanagere, Mandya, Raichur, Bellary, Shivamogga and Belgaum are the major paddy growing and paddy milling areas in the state. In this sense, substantial quantities of agricultural wastes (with the potential for electricity generation) are produced, highlighting the rice husk [3].

\section{TYPICAL HUSK ANALYSIS [BRONZEOAK, 2003]}

Rice husk is a potential material; there are many usage of rice husk either in the raw form or in ash form. Most of the time husk from the mill is either burnt or dumped as waste in open fields and a small amount is used as fuel for boilers, electricity generation, bulking agents for composting of animal manure, etc. The typical husk analysis is shown in the below table [4].

\begin{tabular}{|c|c|c|}
\hline SL. No. & Property & Range \\
\hline 1 & Bulk density $(\mathrm{kg} / \mathrm{m} 3)$ & $96-160$ \\
\hline 2 & Length of husk $(\mathrm{mm})$ & $2.0-5.0$ \\
\hline 3 & Hardness (Mohr's scale) & $5.0-6.0$ \\
\hline 4 & Ash (\%) & $22.0-29.05$ \\
\hline 5 & Carbon $(\%)$ & 35.0 \\
\hline 6 & Hydrogen $(\%)$ & $4.0-5.07$ \\
\hline 7 & Oxygen $(\%)$ & $31.0-37.08$ \\
\hline 8 & Nitrogen $(\%)$ & $0.23-0.329$ \\
\hline 9 & Sulphur $(\%)$ & $0.04-0.08$ \\
\hline 10 & Moisture $(\%)$ & $8.0-9.0$ \\
\hline
\end{tabular}

The properties mentioned in the above table makes rice husk more suitable as fuel for boiler and in turn to produce the electricity. The purpose of this project is to evaluate the exploitation of rice husk resources in and around Belagavi and use this abundant agricultural biomass as a fuel to produce electrical energy and to calculate the payback period.

\section{METHODOLOGY}

To carry out investment grade audit on rice husk power generation in rural part following steps are adopted. 
1)Load survey of particular villages (power requirement)

2) Survey to know the production of the rice and husk available.

3) Survey of already installed power plant.- case study

4)Estimation of electrical energy generation from available Rice husk.

5)Carrying out the investment grade audit, and

6)Finally calculating ROI i.e., the payback period for the investment made.

1) Load Survey of Yallur Villages;

Power consumption of village Yallur, Belgaum, Karnataka, India is obtained from the Electricity Supply authority, Belgaum is shown below. This is observed that maximum of 3.516 lac units are supplied in the month of february and minimum of 2.0lac of units in the month of June of the year.

\begin{tabular}{||c|c||}
\hline Month & Lac Units \\
\hline \hline April & 2.575 \\
\hline May & 2.216 \\
\hline June & 2 \\
\hline July & 2.115 \\
\hline August & 2.21 \\
\hline September & 2.565 \\
\hline October & 3.317 \\
\hline November & 2.417 \\
\hline December & 2.315 \\
\hline January & 3.216 \\
\hline February & 3.516 \\
\hline March & 3.229 \\
\hline
\end{tabular}

Energy Supplied to Yallur Village

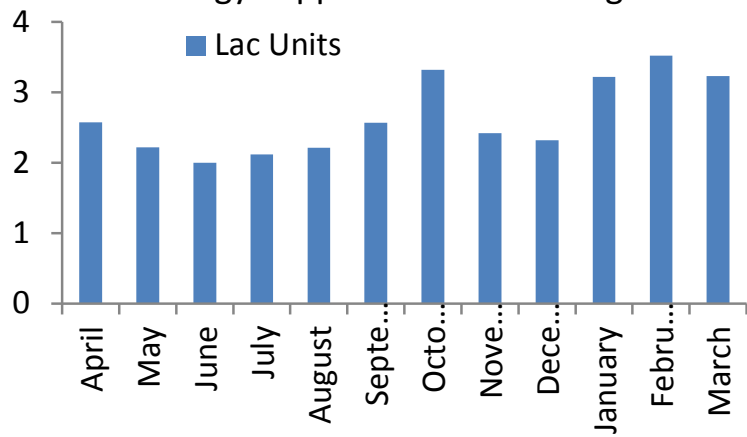

2) Survey to Know the Production of the Rice and Husk Available:

In Belgavi about 84,042 tones of paddy is produced and in accordance $25 \%$ to $30 \%$ of that paddy is husk and that husk is Bio-waste. As husk has oil content, it can be considered as major biomass fuel. Calorific value of paddy husk is $3200 \mathrm{kcal} / \mathrm{kg}$ which is better than bagasse. This husk can be the furnace fuel for power generation units in India as power demand in India is increasing exponentially. Looking at the geographical conditions in and around Belagavi area, Belagavi has moderate rainfall area it comes under transitional area ecosystem and the average rainfall in such area is around $1139.6 \mathrm{~mm}$ annually and has abundant water [5].

The irrigation facilities are also well developed and the areas lie near to bank of Ghataprabha River. Belagavi Taluka has 119 villages in which more than $50 \%$ of villages have rice has main crop "Belagavi Basmati" is the famous rice grown in this area. The major rice growing villages are Honaga, Kakati, Yallur, Kadoli, Jaffarawadi, Devigiri, Ambewadi, Uchagoan, Kanabargi, Ashta, Kednur, Muchchandi, Kangaon, Machche, Jarshapur, Gondwad, Kangaradi, B.K.Kangrali, Sambra, Khadarwadi, Damane, Kanabargi, Kudaremani, Bijagarni etc [6].

\begin{tabular}{|l|l|}
\hline Year & Tonnes \\
\hline 2010 & 84,042 \\
\hline 2009 & 93,405 \\
\hline 2008 & 100,521 \\
\hline 2007 & 99,254 \\
\hline 2006 & 145,984 \\
\hline 2005 & 115,571 \\
\hline 2004 & 49,281 \\
\hline 2003 & 38,279 \\
\hline 2002 & 56,547 \\
\hline 2000 & 119,689 \\
\hline 1999 & 114,147 \\
\hline
\end{tabular}

\section{Rice Production in Tonnes in Belgaum district}

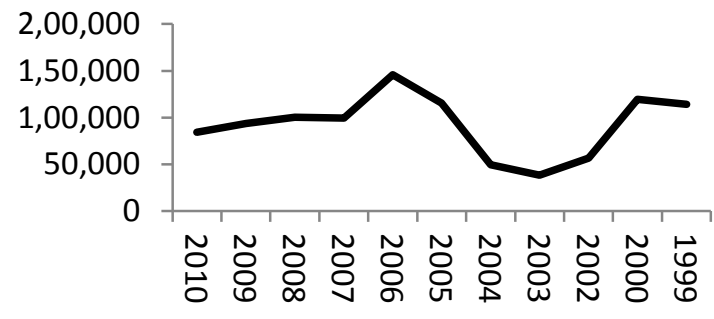

There are 10 to 15 rice mills in an around Belagavi city and around 20 to 25 mills in Belagavi [7] [8].

3) Survey of Already Installed Power Plant;

There are few rice husk power generation plants in Karnataka one of them is the "Koganti Power plant Ltd., Raichur". The following information was obtained from the plant during visit to the plant in the March. Study made to understand the working of rice husk power generation.

- No. of Operating Staff: 07

- Cost of The Plant: 80 Crores ( 2004 )

- Cost Per Unit: Rs.3.9 To 4.2 Per Kwh (Unit)

- Built In Area: 20 Acres

- Alternate Fuel: Wood Pellets, Agricultural Waste.

- Daily Husk Consumption: 220 Tonnes /Day 
4) Electrical Energy availability from rice husk;

\section{1) Steam Calculations;}

The villages selected for project with area and total paddy production is as follows:

\begin{tabular}{|l|l|}
\hline VILLAGE & AREA IN \\
SELECTED & HECTARE \\
\hline Uchagoan & 1714.31 \\
\hline Kadoli & 1739.27 \\
\hline Yellur & 1431.17 \\
\hline \multicolumn{1}{|c|}{ TOTAL AREA } & 4684.75 \\
\hline
\end{tabular}

Average yield per hectare is 2.21 (information from local survey)

Total paddy obtained quarterly $=$ total area $*$ average yield per hectare

$$
=4684.75 * 2.21=10353.31 \text { tonnes. }
$$

Husk is estimated to be about $25-30 \%$ of paddy.

So,

Total husk obtained quarterly $=$ total paddy obtained $* 0.3$ $=10353.31 * 0.3=3106$ tonnes

Husk obtained in one year $=4 *$ total husk obtained quarterly

$$
=4 * 3106=12424 \text { tonnes }
$$

Husk available per day $=$ Total husk obtained in one year $\div$ total no. of working days in a year

$$
=12424 \div 365=34 \text { tonnes }
$$

Husk available per hour $=$ husk available per day $\div$ no. of hours in a day

$$
=34 \div 24=1.42 \text { tonnes } / \text { hour }
$$

One kilogram of husk yields 4.3. Kg of steam. (Study on comparison of boiler efficiency using husk as fuel)

Therefore, 1.42 tonnes of husk will yield

$$
=4.3 * 1.42 * 1000=6106 \mathrm{~kg} \text { of steam. }
$$

4.2) Steam To Kilowatt Conversion;

$1 \mathrm{lbs}=0.453592 \mathrm{~kg}, 1 \mathrm{KW}=3.2$ steam $\mathrm{lbs} /$ hour or $3412.12 \mathrm{BTU}$ or $3600 \mathrm{~kJ} / \mathrm{hour}$

Therefore $1 \mathrm{KW}=3.2 * 0.453592=1.4149 \mathrm{~kg} / \mathrm{hour}, 1 \mathrm{KWh}$ $=1.4149 \mathrm{~kg}$ (steam),

We have $6106 \mathrm{~kg}$ of steam, Assuming boiler efficiency = $68 \%$ and generator efficiency is $85 \%$

Steam proportional to one Kwh of Power generation $=6106 * 0.68 * 0.85=3529.268 \mathrm{Kgs}$ of steam

Energy produced $=3529.268 / 1.4149=2494.36 \mathrm{Kwh}$.

\section{5) Investment-grade audit;}

In most corporate settings, upgrades to a facility's energy infrastructure must compete for capital funding with nonenergy-related investments. Both energy and non-energy investments are rated on a single set of financial criteria that generally stress the expected return on investment (ROI).

The projected operating savings from the implementation of energy projects must be developed such that they provide a high level of confidence. In fact, investors often demand guaranteed savings. The investment-grade audit expands on the detailed audit described above and relies on a complete engineering study in order to detail technical and economical issues necessary to justify the investment related to the transformations [9] [10].

5.1) Cost Analysis;

a)Fuel Management Costs:

i) Fuel cost :

$3 \mathrm{Rs}$ per $\mathrm{kg}$, for 1 tonne $=\mathrm{Rs} 3000 /-$

Per day requirement of rice husk $=34$ tonne

Daily cost of rice husk $=3000 * 34=$ Rs $102000 /-$

Annual cost of fuel is $=34 * 3000 * 365=$ Rs 3.72 crore

ii) Husk transportation :

i.e. $5 \%$ of husk price $=3.72 * 0.05=$ Rs $1860000 /$ -

iii) Start up cost :

i.e. $10 \%$ of daily consumption $=102000 * 0.1=$ Rs $10200 /$ -

b) Fixed Costs:

i) Land cost : 10 lakhs per acre

Land required $=20$ acre, i.e $20 * 10$ lakhs $=$ Rs 2 crore

ii) Insurance cost : $1.767 \%$ of EPC

i.e $30 * 0.01767=$ Rs 53.01 lakhs/year

iii)Salary for operating staff : Salaries For All Operating Staff

$\begin{array}{llll}\text { Sl no. } & \text { Role } & \text { Number } & \text { Salary(Rs) } \\ 1 & \text { Plant Engineer } & 1 & 40000 \\ 2 & \text { Boiler operator } & 1 & 15000 \\ 3 & \text { DCS operator } & 1 & 15000 \\ 4 & \text { RO plant } & 1 & 15000 \\ 5 & \text { Grid operator } & 1 & 20000 \\ 6 & \text { Shift operators } & 4 & 60000 \\ & \text { Total } & 9 & 165000 / \text { month }\end{array}$

Annual expenditure for operating staff $=12 * 165000$ $=$ Rs $1980000 /$

c) Running Costs:

i) Operating and Maintenance cost :

It will be of $4 \%$ of EPC(Engineering Procurement Cost)

We have 30 crore fully automated plant

Therefore 30 crore $* 0.04=1.2$ crore/year

ii) Plant consumption :

200 units per day consumption of the plant

Annual consumption $=200 * 365=73000$ units

Net production :

$=$ total production - plant consumption

$=2500 * 24 * 300-73000 \quad(60$ days for maintenance and overhauling )

$=17927000$ units

d) Annual Expenditure :

$=$ Fuel cost + Transportation cost + Staff Salary $+\mathrm{O} \& \mathrm{M}$ cost + Insurance + Start up cost + Depreciation cost $=3.72$ crore +18.6 lakhs +16.8 lakhs +1.2 crore

+53.01 lakhs +1.02 lakhs +1.2 crore

$=7.0143$ crore $+15 \%$ for extra miscellaneous cost $=8.0664$ crore 
e) Total Income :

Considering 1 unit selling price $=$ Rs $8 /$ - and 300 working days

Income $=($ Total generated units - plant consumption $) * 8$ $=17927000 * 8=\operatorname{Rs} 143416000 /-=14.3416$ crore

f) Annual Savings :

Annual Saving $=$ Income - Expenditure

$=14.3416-8.0664=6.2752$ crore

Net annual savings considering taxes $=6.2752-40 \%$ income (including income tax, sales tax ,service tax , property tax , municipality tax , and discount of 8 to $12 \%$ for biomass generation ) $=3.76512$ crore

g) Installation Cost Per $K W:=\frac{\text { initial investment }+ \text { land cost }}{\text { generating power }}$

Initial investment includes cost of generator, cost of plant accessories, transmission cost. We have taken the value of fully automated plant available in the market. The manufacturers available are Jyoti, BHEL, Thermax etc (ref : PRAVEEN GULVANI(PLANT ENGINEER) )

$$
=\frac{30 \text { crore }+2 \text { crore }}{2500 \text { units }}=128000 \mathrm{Rs} / \mathrm{KW}
$$

Per KW generation cost $=\frac{\text { Total expenditure }}{\text { Total } \text { generated } \text { units }}$

Total expenditure including all taxes and maintenance is $=14.3416-3.76512=10.57648$ crore

Therefore Cost per unit $\quad=\frac{10.57648 * 10^{7}}{2500 * 24 * 300}=5.87 \mathrm{Rs} /$ unit

6) Finally Calculating ROI i.e., The Payback Period for the Investment Made;

$$
\begin{aligned}
\text { Payback Period } & =\frac{\text { Total investment }}{\text { Net annual savings }} \\
= & \frac{32 \text { crore }}{3.76512 \text { crores }}=8.49 \text { years }
\end{aligned}
$$

\section{CONCLUSION}

The values obtained from available amount of rice husk in and around Belagavi area can be used to supply base load of respective village feeders and also it is a new way for farmers to earn money effectively, easily and profitable means of business on their agricultural waste.

Installation of $2.5 \mathrm{MW}$ power plants incurs an initial investment of around 35 crores. As the life of the plant is $20+$ years payback period of 8.49 years is moderate to recover the investment. As rice husk for particular area is limited, a fuel mixing strategy can be used, by which the cost of generation, cost of installation and ROI period can be reduced. Rice husk can be a part of future energy. Once the paddy is grown, every part of the crop is utilized that is paddy, paddy husk, paddy bran and ash obtained from the power plant, so there is no waste at all and as compared to fossil fuels there are no such harmful chemicals released into the atmosphere hence rice husk power generation proves to be efficient, eco-friendly and profitable way of power generation.

\section{REFERENCES}

[1] "List of the country by electricity production" Wikipedia https://en.wikipedia.org/wiki/List_of_countries_by_electricity_prod uction accessed on 03.07.2015
[2] "Handbook of Energy Efficiency and Renewable Energy" edited by Frank Krieth and Yogi Goswami, topic no.2, section 2.3. page 2-21.

[3] "Status Paper on Rice in Karnataka", by M. P. Rajanna Rice Breeder and Head, AICRP (Rice), Zonal Agricultural Research Station, V.C. Farm, Mandya Karnataka, India, Pin 571405.

[4] "A Rice Husk" http://shodhganga.inflibnet.ac.in: - A review, chapter 2, page no.7.

[5] "Average rain fall-KARNATAKA Agriculture Contingency Plan for District": BELGAUM. Page no. 09, http://raitamitra.kar.nic.in/statistics.html\#Rainfall

[6] "Rice production in tones"; http://knoema.com/atlas/India/Belgaum-District/Rice-Production.

[7] "Rice production in Belgaum"; http://knoema.com/atlas/India/Belgaum-District/Rice-Production

[8] "Rice Knowledge Management Portal" http://www.rkmp.co.in

[9] "An investment grade audit" http://en.wikipedia.org/wiki/Energy_audit

[10] "Energy Audit and Demand Side Management" by N. G. Ajjanna a textbook on

[11] "Financial viabilities of husk-fueled steam engines as an energysaving technology in Thai rice mills" -by Chanoknun Sookkumnerd, Nobutaka Ito *, Koji Kito, Department of Environmental Science and Technology, Faculty of Bioresources, Mie University, 1515, Kamihama-cho, Tsu 514-8507, Japan, www.elsevier.com/locate/apenergy, Applied Energy 82 (2005) 64-80.

[12] "Study on Comparison of Boiler Efficiency Using Husk and Coal as Fuel in Rice Mill" JP Yadav and Bharat Raj Singh

\section{BIOGRAPHIES}

Mr. S. B. Halbhavi obtained Bachelor of Electrical Engineering degree from Basaveswar Engineering College, Bagalkot, Karnataka, affiliated to Karnataka University Dharwad, Karnataka in the year 1984, and master degree in Electronics and control from Birla Institute of Technology, Pilani, Rajasthan, in the year 1996, perusing research work with Mahatma Gandhi University Kottayam, Kerala. At present he is working as Associated Professor in the department of Electrical \& Electronics Engineering of Gogte Institute of Technology, Belgaum, Karnataka, India.

Mr. S. G. Kulkarni obtained Bachelor of Electrical Engineering degree from BVB College of Engineering Hubli, Karnataka, affiliated to Karnataka University Dharwad, Karnataka in the year 1986, and Master degree in Electronics and control from Birla Institute of Technology, Pilani, Rajasthan, in the year 1996, Masters degree in Digital Electronics from Gogte Institute of Technology, Belgaum, Karnataka, affiliated to Visvesvaraya Technological University, Belgaum Karnataka. In the year 2011. At present he is working as Associated Professor in the department of Electrical \& Electronics Engineering of Gogte Institute of Technology, Belgaum, Karnataka, India.

Mrs. Vani P. Datar obtained Bachelor of Electrical Engineering degree from KLS, Gogte Institute of technology, Belgaum, Karnataka, affiliated to Visvesvaraya Technological University, Belgaum, Karnataka, in the year 2003, and Master degree in Digital Electronics from Visvesvaraya Technological University, Belgaum, Karnataka in the year 2009. At present she is working as Assistant Professor in the department of Electrical \& Electronics Engineering of Gogte Institute of Technology, Belgaum, Karnataka, India. 